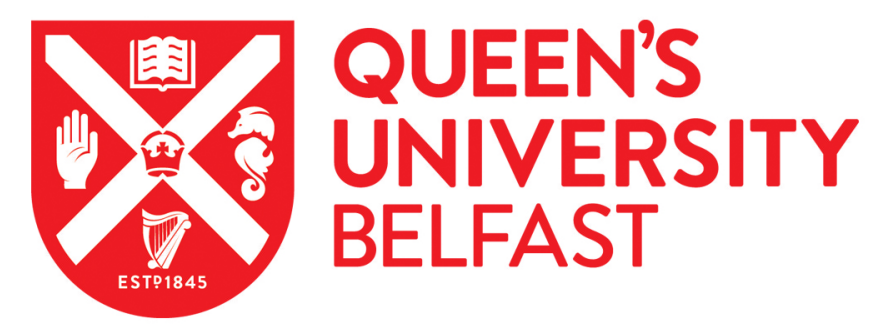

\title{
Simulated eye clinic and virtual eye case: alternative worlds for medical students
}

Williams, M. A., Ross, C., Derbyshire, S., Duffy, S., Morgan, C., O'Gallagher, M., \& Murray, J. (2016). Simulated eye clinic and virtual eye case: alternative worlds for medical students. BMJ Simulation and Technology Enhanced Learning, 2, 127-128. https://doi.org/10.1136/bmjstel-2016-000139

Published in:

BMJ Simulation and Technology Enhanced Learning

Document Version:

Peer reviewed version

Queen's University Belfast - Research Portal:

Link to publication record in Queen's University Belfast Research Portal

\section{Publisher rights}

This article has been accepted for publication in BMJ Simulation \& Technology Enhanced Learning following peer review. The definitive copyedited, typeset version

Williams, MA, Ross, C, Derbyshire, S, Duffy, S, Morgan, C, O'Gallagher, M \& Murray, J 2016, 'Simulated eye clinic and virtual eye case: alternative worlds for medical students' BMJ Simulation and Technology Enhanced Learning., 10.1136/bmjstel-2016-000139 is available online at:http://stel.bmj.com/content/early/2016/09/19/bmjstel-2016-000139

\section{General rights}

Copyright for the publications made accessible via the Queen's University Belfast Research Portal is retained by the author(s) and / or other copyright owners and it is a condition of accessing these publications that users recognise and abide by the legal requirements associated with these rights.

\section{Take down policy}

The Research Portal is Queen's institutional repository that provides access to Queen's research output. Every effort has been made to ensure that content in the Research Portal does not infringe any person's rights, or applicable UK laws. If you discover content in the Research Portal that you believe breaches copyright or violates any law, please contact openaccess@qub.ac.uk. 
The Simulated Eye Clinic

Title page

Submission as a 'Practice Report'.

Full title: Simulated Eye Clinic and Virtual Eye Case: alternative worlds for medical students.

Corresponding author: Dr Michael A Williams

Affiliation: Queen's University of Belfast, UK

Address: $\quad$ Centre for Medical Education, Mulhouse Building, Royal Victoria

Hospital, Belfast, UK, BT12 6BJ

Email: $\quad$ m.williams@qub.ac.uk

Tel.: $\quad 00442890632591$

Authors:

Dr Michael Andrew Williams MSc MD MRCOphth (corresponding author)

Ms Catherine Ross RGN

c.ross@qub.ac.uk

Ms Sonia Derbyshire RGN

s.derbyshire@qub.ac.uk

Dr Stephen Duffy MB BAO BCh sduffy20@qub.ac.uk

Dr Clare Morgan

clares.h.morgan@gmail.com

Dr Michael O'Gallagher MB MSC mog@doctors.org.uk

Dr James Murray MD FRCA james.murray@qub.ac.uk All authors are affiliated to: Centre for Medical Education, Queen's University of Belfast, Belfast, UK.

Word count: 959 
The Simulated Eye Clinic.

\section{Simulated Eye Clinic and Virtual Eye Case:}

\section{alternative worlds for medical students.}

Ophthalmology teaching in our medical school traditionally consists of a two-

week attachment in $3^{\text {rd }}$ year, but an apparent decline in ophthalmic knowledge and skills following this has been observed. Two novel teaching interventions were introduced in $5^{\text {th }}$ year. A simulated eye clinic (SEC) was run for all final year students. The SEC consisted of 4 cubicles with 4 simulated patients (SPs) playing the role of patients with temporal arteritis; an acute oculomotor nerve palsy; a pituitary tumour and sudden loss of vision in the 'only eye' in a patient who had just bought a new car. These were chosen as important cases that could present to non-ophthalmic doctors. Students worked in teams of five, had 15 minutes per station and rotated around all stations. Each of the five students in each team was given a defined role at each station: one called the patient from the waiting room and took a history, one measured the best corrected visual acuity (BCVA), one performed the relevant ophthalmic examination and one made a differential diagnosis, management plan and referral. Referrals were made by students making a phone call answered live by tutors, who sat in another room acting the role of whoever it was that the students had chosen to call. The fifth student was the 'pseudoexaminer', was given a 'mark sheet' and asked to comment on her peers' performances at the end of each station. One of the four stations was the 'on-call station' at which the team, in addition to managing the case, had to field three incoming calls and give advice over the phone: a ocular chemical injury, a painful red eye 
The Simulated Eye Clinic

and new onset floaters. At the end, tutors, students and SPs all gathered for a 20 minute debriefing and discussion.

Self-reported confidence (SRC) in ophthalmic skills measured in $3^{\text {rd }}$ and $5^{\text {th }}$ years. Ethical committee approval was granted. A power calculation was performed prior to recruitment. There were two groups of participants: group 1 consisted of third years who completed an SRC questionnaire at the start $(n=95)$ and end $(n=45)$ of their ophthalmology attachment, and group 2 consisted of fifth year students who completed the same questionnaire at the start $(n=95)$ and end $(n=96)$ of the SEC. The age range, gender balance and declared ophthalmic experience prior to medical school were similar across groups.

There was a significant increase in mean cumulative SRC from the start to the end of the standard third year ophthalmology attachment (Wilcoxon signed rank test, standardized test statistic $=10.2, p<0.001$ ), and a decline in SRC from the end of the third year attachment to the start of the simulated eye clinic (16 to 24 months later) (Mann Whitney $U=368.0, p<0.001$ ). However the single afternoon of the simulated eye was associated with an increase in SRC (Wilcoxon signed rank test, standardized test statistic $=12.0, \mathrm{P}<0.001$ ). There was no significant difference between the cumulative SRC scores at the end of the third year attachment compared to the end of the fifth year SEC (Mann Whitney $U=1445, p=0.001$ ). SRC scores for each skill are shown in table 1 . There were 13 ratings of 'no confidence' across all skills at the start of $3^{\text {rd }}$ year, while none at the end. There were 8 ratings across all skills of 'no confidence' at the start of the SEC but none at the end. At the end of both the 
The Simulated Eye Clinic.

third years' and the fifth years' attachments, the median ratings for each skill were "moderate confidence" or "very confident". 
The Simulated Eye Clinic

Table 1. Absolute SRC levels (recorded on an ordinal scale from 1 to 6 ) for each skill and stage.

\begin{tabular}{|c|c|c|c|c|}
\hline Skill & Stage & $\begin{array}{l}\text { Mean SRC } \\
\text { * (s.d.) }\end{array}$ & $\begin{array}{l}\text { Wilcoxon sig. } \\
\text { test result }\end{array}$ & $\begin{array}{l}\text { Mann-Whitney } \\
\text { sig. test result }\end{array}$ \\
\hline \multirow[t]{4}{*}{ BCVA testing } & Start of $3^{\text {rd }}$ year attachment & $3.8(0.9)$ & \multirow{2}{*}{$\begin{array}{l}p<0.001 \\
z=-6.0\end{array}$} & \\
\hline & End of $3^{\text {rd }}$ year attachment & $5.4(0.7)$ & & \multirow{2}{*}{$\begin{array}{l}p<0.001 \\
(U=726.5)\end{array}$} \\
\hline & Start of $5^{\text {th }}$ year SEC & $4.3(1.0)$ & \multirow{2}{*}{$\begin{array}{l}p<0.001 \\
Z=-7.2\end{array}$} & \\
\hline & End of $5^{\text {th }}$ year SEC & $4.6(0.8)$ & & \\
\hline \multirow{4}{*}{$\begin{array}{l}\text { Direct } \\
\text { ophthalmoscopy }\end{array}$} & Start of $3^{\text {rd }}$ year attachment & $3.2(1.0)$ & \multirow{2}{*}{$\begin{array}{l}p<0.001 \\
Z=-5.7\end{array}$} & \\
\hline & End of $3^{\text {rd }}$ year attachment & $4.7(0.9)$ & & \multirow{2}{*}{$\begin{array}{l}p<0.001 \\
(U=868.5)\end{array}$} \\
\hline & Start of $5^{\text {th }}$ year SEC & $3.5(1.2)$ & \multirow{2}{*}{\begin{tabular}{|l}
$p<0.001$ \\
$Z=-7.0$
\end{tabular}} & \\
\hline & End of $5^{\text {th }}$ year SEC & $4.6(0.8)$ & & \\
\hline \multirow{4}{*}{$\begin{array}{l}\text { Pupillary } \\
\text { examination }\end{array}$} & Start of $3^{\text {rd }}$ year attachment & $4.3(1.0)$ & \multirow{2}{*}{$\begin{array}{l}p<0.001 \\
Z=-5.9\end{array}$} & \\
\hline & End of $3^{\text {rd }}$ year attachment & $5.7(0.5)$ & & \multirow{2}{*}{$\begin{array}{l}p<0.001 \\
U=511.0\end{array}$} \\
\hline & Start of $5^{\text {th }}$ year SEC & $4.4(0.9)$ & \multirow{2}{*}{\begin{tabular}{|l}
$p<0.001$ \\
$Z=-7.1$
\end{tabular}} & \\
\hline & End of $5^{\text {th }}$ year SEC & $5.2(0.7)$ & & \\
\hline \multirow{4}{*}{$\begin{array}{l}\text { Visual field } \\
\text { examination }\end{array}$} & Start of $3^{\text {rd }}$ year attachment & $3.8(1.1)$ & \multirow{2}{*}{$\begin{array}{l}p<0.001 \\
Z=-5.9\end{array}$} & \multirow{3}{*}{$\begin{array}{l}p<0.001 \\
U=638.5\end{array}$} \\
\hline & End of $3^{\text {rd }}$ year attachment & $5.5(0.7)$ & & \\
\hline & Start of $5^{\text {th }}$ year SEC & $4.2(1.0)$ & \multirow{2}{*}{$\begin{array}{l}p<0.001 \\
Z=-7.7\end{array}$} & \\
\hline & End of $5^{\text {th }}$ year SEC & $5.1(0.8)$ & & \\
\hline \multirow{4}{*}{$\begin{array}{l}\text { Extraocular } \\
\text { movement } \\
\text { exam }\end{array}$} & Start of $3^{\text {rd }}$ year attachment & $4.3(1.1)$ & \multirow{2}{*}{$\begin{array}{l}p<0.001 \\
Z=-5.8\end{array}$} & \multirow{3}{*}{$\begin{array}{l}p<0.001 \\
U=817.0\end{array}$} \\
\hline & End of $3^{\text {rd }}$ year attachment & $5.6(0.6)$ & & \\
\hline & Start of $5^{\text {th }}$ year SEC & $4.6(1.1)$ & \multirow{2}{*}{$\begin{array}{l}p<0.001 \\
Z=-6.9\end{array}$} & \\
\hline & End of $5^{\text {th }}$ year SEC & $5.2(0.7)$ & & \\
\hline
\end{tabular}

* Key: 1=no confidence, 2=very low confidence; 3=low confidence; 4=some confidence; 5=moderate confidence; 6=very confident.

A year later a PC-based virtual eye clinic (VEC) replaced the third nerve palsy station (figure $1 \mathrm{a}-\mathrm{c}$ ). This was created using a 3D gaming engine to emulate an ophthalmic consultation, developed by MW and technologyprojectsmanagement.com. Students were presented with a 3D world and asked to gather the history and make decisions on investigation and management, using drop down menus, their decisions driving branching within the simulation. They also could conduct simulated examinations of visual fields to confrontation and eye movements. Exemplar quotations from 
The Simulated Eye Clinic.

students with reference to the VEC included comments that the advantage of a virtual case were that "it was fun and interactive", and that "you could work at your own pace". It "stimulates a real time sensed hospital experience", but it was "quite slow with no audio", and would be "more useful for home studying". "More cases would be great!."

A future study should examine the extent to which the downward trajectory of SRC continues following the SEC. Furthermore it is unknown whether alternative refresher courses than the SEC would be as effective for most students. An unexpected learning need observed during the SEC was students' lack of familiarity with calling a patient from the waiting room and assessing the patient from the first contact, for example noticing, or not, the SP acting out a bitemporal hemianopia en route to the cubicle.

It is unclear how closely, or not, SRC in ophthalmology correlates with actual competence. However while self-assessment measures have been used as measures of the impact of educational interventions in many studies [1], a concern is that self-assessment is more complex than can be captured in a questionnaire [2].

The SEC was designed to allow students to explore the words patients use to describe visual symptoms, practice measuring and describing BCVA accurately, reactivate ophthalmic clinical skills and to rehearse non-technical skills such as team work, communication and decision making in a safe environment. Our experience indicates it was feasible, and the data collected suggests it was effective with regard to self-reported confidence. The VEC also worked in practical terms, complemented the simulated cases, but may 
The Simulated Eye Clinic

be more appropriately used in a different setting. High quality evidence needs sought of the non-inferiority of the VEC compared to other means of learning.

- Acknowledgements: Dr Maria Napier and Dr Donal McCullagh for help with data collection. Neville Rudd and Andy MacPherson from technologyprojectsmanagement.com for their expertise.

- None of the authors have any competing interests to declare.

- $\quad$ This work was presented as a poster at the Association for Medical Education (ASME) Annual Conference, Belfast, July 2016.

- No funding was sought or used for this study.

Contributorship statement.

Dr Michael Andrew Williams conceived of, designed and delivered the SEC and VEC, and the associated study. He got ethical committee approval and wrote the first draft of the paper.

Ms Sonia Derbyshire helped design the study and collected data.

Ms Catherine Ross helped design the study and collected data.

Dr Stephen Duffy played a major role in collecting data.

Dr Clare Morgan collected and analysed data on the VEC

Dr Michael O'Gallagher played a major role in collecting data.

Dr James Murray advised on the study and oversaw the running of the study.

\section{LEGENDS FOR FIGURES.}

Figure 1. Screenshots from the virtual eye clinic.

1a. The consultation 
The Simulated Eye Clinic.

1b. Home screen

1c. Extraocular movement testing

\section{REFERENCES.}

1. Chan TY, Rai AS, Lee E, Glicksman JT, Hutnik CM. Needs assessment of ophthalmology education for primary care physicians in training: comparison with the International Council of Ophthalmology recommendations. Clinical ophthalmology 2011;5:311-9 doi: 10.2147/OPTH.S17567[published Online First: Epub Date]|.

2. Eva KW, Regehr G. Self-assessment in the health professions: a reformulation and research agenda. Academic medicine : journal of the Association of American Medical Colleges 2005;80(10 Suppl):S46-54 